\title{
Caspian region: a focus on Azerbaijan - oil, natural gas, environment and resource management
}

\author{
Elif Hatun Onal-Kilicbeyli ${ }^{1}$, Elnur Hasan Mikail2,, ${ }^{2,}$ and Hakan Çora ${ }^{3}$ \\ ${ }^{1}$ Adana Alparslan Turkes Science and Technology University, Turkey \\ ${ }^{2}$ Kafkas University, Kars, Turkey \\ ${ }^{3}$ Istanbul Okan University, Istanbul, Turkey
}

\begin{abstract}
At In this paper, it was attempted to examine the oil, natural gas, environment and resource management with a focus on Azerbaijan with details on history, geography, political, social, and economic developments of Caspian zone. The developments realized by countries over time are important with regard to what course they will follow in the future. The study also attracts attention to the environmental and economic importance of Lake Hazar, which is important for the country. Like other Turkic Republics that have gained their independence, the main economic goal of Azerbaijan is to realize a strong economic structure that can stand on its own in order to achieve economic independence as well as political independence in order to coordinate natural and environmental advantages.
\end{abstract}

\section{Introduction}

The national economy should be restructured to achieve which ones economic goals. For the goals of economic restructuring, Azerbaijan will develop its own economic policies as an independent state instead of determining the country's resources by an external center. It is envisioned that a total investment of 40 billion USD dollars will be made for the production of energy resources of the Caspian Sea. Azerbaijan will receive $80 \%$ of the oil sales revenue. International foreign companies will get a share in return for the capital they invest. It was discussed what kind of change Azerbaijan, as a part of Caspian zone, underwent for long years of Russian occupation and what this change meant for the country. Regarding that, it was also examined how the events in the world political arena would affect Azerbaijan and whether the country that had left the Soviet Union and made efforts to gain a respected place in the international arena in recent years would become successful.

*Corresponding author: emikail@turansam.org 


\section{General perspective of Azerbaijan}

\subsection{Geographical structure}

The Republic of Azerbaijan is located in the Caucasus, between the Greater Caucasus and the Lesser Caucasus. The most important feature of the Republic of Azerbaijan with regard to the location is its strategic importance on trade routes. Geographically, the total length of its borders is $3600 \mathrm{~km}$. Georgia (322 km) and the Dagestan Autonomous Republic (284 km) of the Russian Federation are located in the north, the Islamic Republic of Iran $(432+179 \mathrm{~km})$ is located in the south, Armenia $(556 \mathrm{~km}$ ) and the Republic of Turkey (an $11 \mathrm{~km}$ long common border with the Nakhchivan Autonomous Republic) are located in the west, and the Caspian Sea $(180 \mathrm{~km}$ ) is located in the east. It has a total area of $86600 \mathrm{~km}$ (Abutalibov and Mammadov, 2013).

The average altitude of Azerbaijan above sea level is 657 meters. The mountainous terrain consists of the Lesser Caucasus, Greater Caucasus, and the Talysh Mountains. The Kur-Avas plain has the largest flat area. The lowest and highest elevations are 28 meters and 4485 meters, respectively [1]

The climate of Azerbaijan, which has 9 of 11 types of climate in the world, is affected by the cold air masses of the Greater Caucasus from the north, warm tropical air currents of the Lesser Caucasus from the south, and the Caspian Sea. Since its eastern and central parts are low and plain, winters are warm, and summers are very hot. The annual amount of precipitation that falls to the Southeastern Region is $1200-1400 \mathrm{~mm}$. Other regions have an arid and semi-arid climate [2]

Most of the agricultural activities are carried out around the Kur and Aras rivers. Although agricultural products are sufficient to meet the needs of the domestic market of Azerbaijan, agricultural industrial technology has not been modernized [3]. Azerbaijan is a country rich in underground submarine hydro-carbon resources. Its main resources are lead, zinc, copper, iron ores, barite, alunite, cobalt, arsenic, limestone, cyanite, metallic salt and rock salt. There are also small amounts of precious metals such as gold and silver. The most important underground treasure of the country is oil [4]. Oil and natural gas are extracted in Bahar, Kum Island, Neft Stones, Neftchala, and Sangachal.

\subsection{Transportation}

Azerbaijan has a developed transportation system.

Railway: $2090 \mathrm{~km}$.

Highway: $30400 \mathrm{~km}$

Marine transportation: performed through the Caspian Sea.

Air Transportation: Centrally, it has two major airports, Ganja Airport and Baku Heydar Aliyev Airport. Flights are made from Baku and Ganja airports to other parts of the world such as Ankara, Istanbul, London, Paris, Moscow, Tashkent, Astana, Bishkek, Beijing, Dubai, Milan, and Kyiv. Azerbaijan Airlines is the largest airline company in the country, and the head office of the company is located at Baku Heydar Aliyev Airport in Baku. Azerbaijan, which ranks first in terms of the number of airports in the Caucasus, also has airports in Lankaran, Shaki, Yevlakh, Nakhchivan, Zaqatala, and Khankendi [5].

\subsection{Demographic and social institutional structure}

It is reported that the population of Azerbaijan was 9,047,000 people on average in 2009. Of the population, $52 \%$ and $48 \%$ live in urban areas and rural areas, respectively. The population 
per $\mathrm{km}^{2}$ is 93 . While $1,807,000$ people live in Baku, 301,000 and 287,000 people live in Ganja and Sumqayit, respectively. The capital of Azerbaijan is Baku, and Ganja, Sumqayit, and Lenkaron are among the most important cities [5]. While Azeri Turks constitute $90 \%$ of the Azerbaijani population, the others (Kyrgyz people by $66 \%$, Russians and Ukrainians by $13 \%$, Uzbeks by $14 \%$, the rest are Tatars, Kazakhs, Germans, Muslim Chinese (Dungan) Uighur, Turks, Armenians, and Belarusians) constitute $10 \%$ of it. There are 20 cities in the country, and the most important ones among them are Bishkek, Osh (Russians, Talysh, Lezgins, Jews, Armenians, etc.) [4].

It is observed that education in Azerbaijan is at a very advanced level compared to other Turkish State Communities. According to the statistical data for 1991, 1,503,000 students were studying in 4775 schools. Nowadays, the number of schools has reached 5000, and the number of students has reached 1,600,000 [6]. The country has 6500 cultural facilities, 4605 libraries, 125 museums, 125 music schools, 43 public theatre halls, and 3680 cultural centers. The literacy rate is $99.5 \%$ [5]. There are a total of 49 private and public universities, and these universities provide education to many Turkish and international students, and Azerbaijan is considered among the countries that provide quality education among the Eastern Bloc countries [7].

The official language of Azerbaijan is Azeri Turkish. The literacy rate in the country was $97.3 \%$ in 1999. Azerbaijan is a secular state as a republican structure [8]. While $96 \%$ of the people are Muslims (85\% Shiite - Jafari), 3-4\% of them are Christians (the majority are the Russian Orthodox Church, Georgian Orthodox Church, and Malakan), and a very small number of them are Jewish. However, since religious devotion is nominal in Azerbaijan, the percentage of believers in practice is much lower.

Azerbaijani Turks, who constitute a large part of the population in Azerbaijan, are Muslims. However, due to the intense atheist propaganda made by nearly 70 years of Communist rule and the reaction against the fundamentalist Islamic propaganda originating from the Islamic Republic of Iran, religious orientations in Azerbaijan have become a cultural color rather than acquiring an Islamic character. Nevertheless, this does not mean that radical fundamentalist movements do not exist in Azerbaijan [9].

\subsection{Political background}

Various sources have explained that the arrival date of the Turks in Azerbaijan corresponds to the times before Christ, the Saka-Scythian period. It is also known that while some of the Hun Turks moved from the Balkans to Thrace between 395-96 AD, some of them arrived in Anatolia through the Caucasus and after coming to the Central Anatolia Region, they returned to the north via Azerbaijan-Baku [7]. The history of Azerbaijan, which is spread over these wide geographies, can be divided into periods as follows:

Azerbaijan during the Seljuk period

Atabegs and Ilkhanate periods

Azerbaijan during the Safavid period

Avshar and Qajar period

Khanates period

Independent Azerbaijan period (1918-1920)

Azerbaijan during the Soviet Union period

Independence period

The Azerbaijan Democratic Republic, which was the first democratic and secular state of the Muslim world, was established in 1918. However, although it joined the Soviet Union in 1920, Azerbaijan regained its independence in 1991. The independence of the Republic of Azerbaijan adopted in 1991 was governed by the authority granted by the law on reestablishment [8]. 
In 1991, Azerbaijan became one of the independent Turkic states and took its place in the international arena as one of the active members of the Turkic Council and TURKSOY. In line with this framework, it has diplomatic relations with 158 countries and membership to 38 international organizations. The Republic of Azerbaijan, which is autonomous and independent nowadays, is governed by the Constitution adopted by a referendum on November 12, 1995. According to this Constitution, the Azerbaijan State is a democratic, secular, and unitary republic. The principle of separation of powers was adopted in the Constitution. While the legislative power is attributed to the National Assembly, the executive power is attributed to the President, and the judicial power is attributed to independent courts [9].

\section{Economic structure of Azerbaijan}

\subsection{Main structure of the economy}

The economy of the Caspian Lake depends mainly on the wealth of oil and natural gas resources, the diversity of energy and the ease of extracting these resources to the earth. At the same time, the delivery of energy resources -as oil and naturel gas - from the Caspian Lake geography to the international market is another advantage. Oil and gas resources, which are the basis of the economy of the Caspian region, for these reasons, both in the USSR and in the post-Soviet period, that is, in the 1991, Oct. 18th, when Azerbaijan was stayed as a 'Sovereign State'. Since 1991 year, Caspian energy sources are important for both Asia and Europe, in short, the entire world fossil fuel market. Oil, which is one of the important energy and industrial raw materials of the world today, consists of the composition of solid, liquid and gas hydrocarbons in different proportions. It forms Petroleum, 30\% paraffins, $40 \%$ naphthenes, $25 \%$ aromatic hydrocarbons. The remaining $5 \%$ are oxygen, nitrogen and sulfur compounds. Hydrocarbons or hydrocarbons are called natural gas if they are in gas form, oil if they are liquid, and bituminous shale if they are in [10].

In Azerbaijan, which gained its independence in 18th, Oct.1991, the transition to a freemarket economy from the state structure, which dominated production and property alone, was initiated, and the necessary legal infrastructure works were started to this end. Privatization was started in agriculture, industry, and the services sector, and private ownership was allowed [11].

After the end of the Karabakh War in 1994 with a ceasefire, the economic stability measures that were initiated in 1995 and implemented especially in 1996 yielded results, and stability in the economy was achieved. While the growth of $4.7 \%$ was achieved in the economy in 1999 , there was a decrease of $8.5 \%$ in the consumer general price level. Manat, the national currency, lost 13\% value against the dollar in 1999 [12]. The economic crisis experienced in Russia showed its effect in Azerbaijan since the second half of 1998. The economic recession in 1999 affected almost all companies and led to the closure or downsizing of many private companies. Foreign-invested companies were also affected by this process [7]. The bottleneck in the privatization of industrial plants in the country under the effect of the economic recession in 1999 causes today's Azerbaijan to experience severe problems in production. The Azerbaijani economy has been experiencing a bottleneck due to the energy, raw material supply and processing problems of many industrial plants that have completed their economic and technological life, and debts to employees and other enterprises [13]. Furthermore, the Azerbaijani economy has lost its ability to compete in foreign markets with its product quality and price. Unemployment has become a serious problem due to the inability to operate large-scale industrial facilities that provide a significant portion of employment. 
Azerbaijan has enormous economic potential, especially in the energy sector. Industry experts indicate that the Caspian reserves of underground resources such as oil, etc. as a whole are close to those of the North Sea reserves [14]. Therefore, almost every big oil company in the world has an interest in Azerbaijan. The Azerbaijani government issued many "Production Sharing Decisions" to help the development of this potential [7].

Approximately $50 \%$ of the total income in the Azerbaijani budget comes from oil export. Of Azerbaijan's total export, $90 \%$ also consists of oil and natural gas. The pipelines to transport these products are also extremely important for a country that is so dependent on oil and natural gas. The development of pipelines plays a key role in increasing Azerbaijan's oil and gas export.

The Caspian Sea oil is transported from Baku to the Black Sea by two important oil pipelines. While one of these pipelines passes through Suspa in Georgia, the other one passes through Novorossiysk, one of the important ports of the Black Sea. According to Russia's energy policy, Caspian Basin oil is first transported to Samara Oblast. From here, it is combined with West Siberian and Ural oil and sold to the international market through different pipelines according to the Russian energy supply plan [15].

The Caspian Pipeline Consortium (CPC), a shipper-owned oil pipeline that transports Caspian oil to the Russian Black Sea port of Novorossyisk, remains the only oil export pipeline on Russian territory to date under the control of state-owned company Transneft. The CPC, completed in 2001, was from the beginning the product of a fragile balance of power between countries that wanted to maintain control of hydrocarbon flows and financially private companies that needed it. Despite its economic success, the future of the CPC currently rests on a partnership dispute that pits Russia against private shareholders [7]. Furthermore, it is known that 50 million tons of crude oil is pumped annually through the Baku-Tbilisi-Ceyhan Oil pipeline established with an agreement signed by TurkeyAzerbaijan-Georgia and that there are eight pumping stations on the pipeline. The proven amount of oil in the Caspian region is approximately 34 billion barrels. The estimated amount is 270 billion barrels. It is estimated that 3.7 million barrels of oil per day would be produced in the region in 2010 .

\subsection{Transformation period on the national economy}

Transformation can be defined as a dynamic historical process. The main purpose of this historical process is to ensure the transformation and adaptation of all elements of society according to the new system adopted. The transformation process starts with a certain system and ends in the same system [9].

The transformation of the economic system includes the following issues:

The economic transformation includes issues such as financial processes, macroeconomic indicators (e.g. public budget, monetary transactions, liberalization of trade, and income level).

The public transformation includes issues such as the formation of new economic foundations to eliminate the old socialist system [7].

The economic transformation includes issues such as reducing the shortcomings of the economy, military expenditures, industry, marketing operations, and the establishment of a market economy of national income.

\subsection{Institutional transformation}

Transition to the Democratic State Institution: According to the Marxist-Leninist doctrine, the socialist state was the state of the "dictatorship of the proletariat." The function of this state was to realize first the socialist stage and then the communist stage [9]. 
Azerbaijan was previously a socialist state when it was a member of the USSR. However, after the dissolution of the USSR, it declared its independence, switched to a free market economy and decided to act together with international institutions and organizations. Private enterprises developed in a short time after the transition to private ownership [12].

Transition to the Private Enterprise Institution: During the transformation process, certain decisions were taken and put into practice to make the private enterprise institution functional in the country. The most important consequences of these decisions are the laws "Sahibkarlig Fealiyeti Haggında [About Entrepreneurial Activity]" and "Müesseler Haggında [About Institutions]."

Transition to the Competition Authority: After the transition to the market economy, producers and consumers in Azerbaijan began to decide by themselves what, how much, and where they would produce and consume.

\subsection{Structural adjustment decisions and application}

In this chapter, the radical changes of Azerbaijan in the economic field are examined. It was attempted to examine political and economic attitudes towards the monopolistic market along with the reform movement in the means of production.

Concerning the Law on Property and Business adopted in the first years of independence, Azerbaijan tended to renew the old means of production and restructure them as required by the capitalist system during the transition to the market economy. The socialist economic system that eliminated private enterprise transferred its monopolies to Azerbaijan along with its collapse. One of the decisions taken in the first years of independence was the legal regulations regarding the elimination of monopolies [4]. The relevant laws were enacted, which are the "Law on Anti-Monopoly Activity" and the "Law of Privatization." The purpose of the first law was to establish the legal framework for the elimination of monopoly and the prevention of possible monopolies. The purpose of the second law was to determine the legal ways of transferring public monopoly enterprises to the private sector [5].

According to the official data for 1998, 6644 small enterprises were privatized and transferred to the private sector, 547 large enterprises were transformed into joint-stock companies, and laws were enacted for their future privatization [12].

Both the use of privatization revenues and the control of the resources spent on privatization were not realized within the framework of a specific plan and program, and consequently, the success of privatization efforts was jeopardized.

\section{Economic importance of the Caspian Sea}

The Caspian Sea is the world's largest inland water cover, in other words, the inner lake with $424,300 \mathrm{~km}^{2}$. The water volume is 80 thousand cubic meters, and the water level is $-28 \mathrm{~m}$. It has a length of $1050 \mathrm{~km}$ and a width of $450 \mathrm{~km}$. Its deepest part is $1098 \mathrm{~m}$, and its average depth is $180 \mathrm{~m}$. Its water is slightly salty. Approximately 130 large and small rivers and streams flow into the Caspian Sea.

The countries with a coast on the Caspian Sea are Russia, Azerbaijan, Iran, Turkmenistan, and Kazakhstan. The Caspian Sea, which takes a privileged place among the seas in the world in terms of the importance of its economic and biological reserves, establishes economic relations between the Volga shore, Transcaucasia, North Caucasus, Central Asia, and Iran through the maritime economy, and the existing relationships are improving [16]. The suitable geographical location, rich biological reserves, rich oil, natural gas, phosphorite, mirabilite, salt, iodine, bromine reserves, and the healing and recreational facility characteristics of the coastal land increase the economic, strategic, social, and ecological importance of the Caspian Sea. 
The Caspian Sea comprises strategically important oil fields and fish stocks, and oil and gas pipelines, which are of vital importance for coastal states, also pass through the Caspian region.

At the beginning of the 19th century, there was a significant competition and conflict between Azerbaijan and Kazakhstan over oil, fish, and salt in the Caspian Sea [17]. The same conflict continues nowadays. The largely undiscovered energy reserves of the Caspian Sea were discovered and opened for investment after the dissolution of the Soviet Union. In addition to the large reserves that were also known before the dissolution of the Soviet Union, rich new oil and natural gas reserves have made the Caspian Sea the Persian Gulf of the 21st century [18].

The importance of the Caspian Sea for Azerbaijan is equal to the importance of oil for the world. Countries are sometimes very incapable of using the wealth that their geography has provided to them, and since they do not want to share this "black gold" given to them by God with strong countries (which is no longer a country, it is now under the guidance of companies that direct global capitals), it is sometimes taken from them directly and sometimes indirectly [19].

After Azerbaijan gained its independence, there have been games on the country, the Nagorno-Karabakh region was occupied by Armenia with a fait accompli, and an attempt to weaken the country was made. However, as a result of the international political maneuvers implemented by the Azerbaijani government, the oil and natural gas deposits in the country could not be controlled by the colonialist states [20].

\subsection{The history of oil and natural gas in the Caspian Sea}

The oil and gas exploitation in Azerbaijan has a long history dating back to the 7th and 8th centuries in various written sources. Starting from the middle of the 17 th century, oil was started to be extracted mechanically in Bibi-Heybat (near Baku).

The oldest oil wells were dug by hand. According to written historical sources, the first simple well with a depth of 35 meters was dug in Absheron in 1594. It is stated that there were 50 wells in 1806 and 120 oil wells in 1821 in the Absheron peninsula [21].

In the middle of the 19th century, the most productive oil well could produce at least 10 barrels of oil per day. Despite the presence of large oil stocks on land, the oilmen also tried to investigate the structure of the regions close to land in the Caspian Sea.

The first modern oil well in the world was dug using mechanical methods in the BibiHeybat region near Baku in 1848. This incident took place 11 years before the oil well dug in Pennsylvania, the USA. At the beginning of 1870, the drilling of oil wells became widespread throughout Azerbaijan. During these years, engineering and technology were highly developed and supported by legislation with certain laws [18].

After 1872, it is observed that the oil industry in Baku developed rapidly as a result of modern methods and technological developments. Before this date, the tax farming system, which prevented the development of the oil industry, was abolished. After this development, the participation of foreign capital, on the one hand, and the expansion of the oil geography in Absheron, on the other hand, the acceleration of oil production and the development of oil production techniques were ensured in creating favourable conditions for the growth of the oil industry [22] These lands were mostly leased by Russian and Armenian investors. It is observed that Azerbaijani H. Z. Tagiyev was among the lessees. 6.2 million tons of oil were produced from the oil fields within 12 years, which was followed by an expansion in oil refining. 


\subsection{Reserve amount of Caspian Oil}

It is estimated that there are 100-200 billion barrels of oil in the Caspian Sea. This rate is the biggest number after the Middle East region, which has reserves of 700-900 billion barrels. There are also those who say the opposite. John Chipman, the President of the International Institute for Strategic Studies (IISS), argues that the Caspian oil, which is considered to be one of the most important energy resources of the world due to its oil reserves, "may be of high cost and its reserves may be insufficient." Chipman also argued that "developing new oil fields and building oil pipelines when oil prices are low can be inefficient." [23].

Different opinions can be suggested about for what purpose Chipman put forward this thesis. Since Azerbaijan is a country that has just opened to the market, it may have been kept out of sight by big companies, and they may have aimed to get a share for themselves secretly. Another perspective may be that while the Middle East oil is so popular and the world countries keep an eye on this geography, the reserves that can be used as "reserve storage" after the oil produced there is finished are not desired to be put on the market for now [20]. Such possibilities can be increased. Some may call these views conspiracy theories. However, the whole world is watching with horror how the strong exert their authority over the weak [22]. The instances of Iraq and Kuwait stand out as very recent examples. Thirty billion tons of oil and natural gas have been detected in the Azerbaijani sector of the Caspian Sea. The total reserves are estimated to be 100 billion tons. In the annual report of IISS, it is explained that the reliability of the Caspian oil will become questionable if the oil prices are between 12 and 25 dollars per barrel. Nowadays, oil prices are around 70-75 dollars per barrel. It can be predicted that oil production will not be as expensive as IISS argues. The transportation of Azerbaijani natural gas to Europe is on the agenda today.

Like other Central Asian sovereign countries that have gained their independence, the main economic goal of Azerbaijan is to realize a strong economic structure that can stand on its own in order to achieve economic independence as well as political independence. The national economy should be restructured to achieve this economic goal. For the goal of economic restructuring, Azerbaijan will develop its own economic policies as an independent state instead of determining the country's resources by an external center.

It is envisioned that a total investment of 40 billion USD dollars will be made for the production of energy resources of the Caspian Sea. Azerbaijan will receive $80 \%$ of the oil sales revenue. Foreign companies will get a share in return for the capital they invest [23].

The Azerbaijan International Operating Company (AIOC) is responsible for the operation and development of the Chirag, Azeri, and Guneshli deposits. These three deposits have a total of 3.8 billion barrels of oil reserves [12]. These deposits constitute the majority of Azerbaijan's total reserves. The annual production in these deposits will reach approximately 35 million tons by 2010. It is estimated that there are also more than 2.5 billion tons of oil reserves in the Azerbaijan part of the Caspian Sea [14].

Azerbaijan has 65 oil and natural gas fields. Although 22 of these fields are ready for oil production, oil production does not take place (off-shore). In the other 43 regions, there is active oil production (on-shore). The production sharing agreements of SOCAR are available in these fields. The agreements (PSA) cannot be easily privatized because they are made for 25 or 30 years, based on SOCAR's experience.

\section{Conclusion}

The purpose of this study, which is focused on Azerbaijan, is to introduce the country and to provide information about its history, geography, political, social, and economic developments. In the second chapter, it was discussed what the Caspian Economy means for the country. In the third chapter, the developments that Azerbaijan experienced in its political 
life and the role of nationalism in these developments were mentioned, and their importance was presented.

After the collapse of the Soviet Union, Azerbaijan entered a period of accelerated development, both culturally, economically and politically. The neo-capitalism concept implemented in the new-sovereignty country questioned both the entire institutional structure and the values of society. It was a time of complete transformation. Although it may seem easy, it turns out that change will not be easy given the Republic of Turkey after the Ottoman Empire. Azerbaijan needs to establish the 'institutional strong structure' that it is looking for as soon as possible. Although this article is not included in the study, it is the strong state identity of Azerbaijan that will stop Armenia's unjust occupation of Nagorno-Karabakh and its military attacks. This country has a strategic but also dangerous weapon like energy in a mixed geography. It will attract the attention of the Colonial States. "No nation has friends who have only interests." Azerbaijan should keep this in mind and act accordingly. Because of the geography in which Azerbaijan is located, it can move limited cross-border. But it needs innovative investments with a broader vision for a sustainable economy and a sustainable Republic. Only in this way can it keep its own young population on its own national territory, preventing the brain drain. For this reason, it is necessary to use its wealth in the current situation for long-term rational investments.

If Azerbaijan is trying to build its national economy based solely on oil and natural gas, it should create an investment area for its future after resources are exhausted. Otherwise, it is clear that other states whose resources are depleted will fall into position. In the TwentyFirst Century, considering only natural gas and oil resources for the restructuring of Azerbaijan, this is a serious risk to the future of the country. Currently, the national economy of Azerbaijan is based on oil and natural gas. The submarine resources of the Caspian Lake are limited in life, but the sovereign presence of the countries is unlimited. The Azerbaijani state must maintain the sovereignty of the nation within the framework of a safe and secure life with an economic, social and livable environment, without being bound by national borders for the future, and then in the same place of Azerbaijan. Otherwise, it may be possible to partially or completely lose its national integrity. The Caspian Sea and Border countries are located in a difficult geographical region and have the strongest region of the Caspian economy; from this point of view, Azerbaijan must realize unique means of renewal, taking into account strategic, political, economic and social sides. Caspian Lake has other values than underwater and hydro-carbon fuels. These resources are ready to create a climate of 'Regional Peace' between the countries bordering the Caspian Lake and the countries of Central Asia. For this reason, Azerbaijan has to deal with global environmental issues, global warming, be specific to these issues, and consequently create its 'Rational Ecopolitics' as part of Environmental Security and Sustainable Development. With all these innovative global changes on politics, Azerbaijan will also be able to make a significant contribution to world peace efforts.

\section{References}

1. R. Abutalibov, R. Mammadov, The investment opportunities in non-oil sector of Azerbaijan Republic in modern world, SSRN Electronic Journal (2013) https://doi.org/10.2139/ssrn.2326974

2. K. Aliyev, Expected macroeconomic impacts of the accession to WTO on Azerbaijan economy: Empirical analysis, SSRN Electronic Journal (2014) https://doi.org/10.2139/ssrn.2419175

3. K. Aliyev, O. Nadirov, How fiscal policy affects non-oil economic performance in Azerbaijan? SSRN Electronic Journal (2016) https://doi.org/10.2139/ssrn.2884267 
4. K. Aslanli, Fiscal sustainability and the state oil fund in Azerbaijan, Journal of Eurasian Studies 6(2), 114-121 (2015) https://doi.org/10.1016/j.euras.2015.03.004

5. Azerbaijan, Construction, development, planning \& property, Foreign Law Guide, https://doi.org/10.1163/2213-2996_flg_com_323231 (n.d.)

6. O. Bayulgen, Foreign capital in Central Asia and the Caucasus: Curse or $\begin{array}{llll}\text { blessing? Communist and } & \text { Post-Communist }\end{array}$ (2005) https://doi.org/10.1016/j.postcomstud.2005.01.007

7. N. Bairamli, V. Kostoglou, The role of savings in the economic development of the Republic of Azerbaijan, International Journal of Economic Sciences and Applied Research, ISSN 1791-3373, Kavala Institute of Technology, Kavala 3, 2, 99-110 (2010)

8. J. Chunqing, Z. Zaixu, Regarding the role of oil \& gas industry on social infrastructure development in Azerbaijan and the solution of ecological problems, IOP Conf. Series: Earth and Envir. Sci. 189, 052004 (2018) doi :10.1088/1755-1315/189/5/052004

9. A. Dellecker, Caspian Pipeline Consortium, Bellwether of Russia's Investment Climate?. Russia/NIS Center. Paris (2008)

10. S. Hasan, Socio-Economic Structure of Azerbaijan in the New Century (Istanbul, 2004)

11. F. Hasanov, F. Huseynov, Real exchange rate misalignment in Azerbaijan, SSRN Electronic Journal (2009) https://doi.org/10.2139/ssrn.1788664

12. S. Humbatova, S. Tanriverdie, I. Mammadov, N. G. Hajiyev, Impact of investment on GDP and non-oil GDP in Azerbaijan, Entrepreneurship and Sustainability Issues 7(4), 2645-2663 (2020) https://doi.org/10.9770/jesi.2020.7.4

13. S. Humbatova, R. Gasimov, N.G. Hajiyev, The impact of oil factor on Azerbaijan economy, International Journal of Energy Economics and Policy 9(4), 381-387 (2019) https://doi.org/10.32479/ijeep.8001

14. B. Janusz-Pawletta, Geography, politics and economy in the caspian region, The Legal Status of the Caspian Sea 9, 12 (2014) https://doi.org/10.1007/978-3-662-44730-7_2

15. E.H. Kilicbeyli, Russia and Eurasian Energy Politics, Politics on Central Asia and Caucassia (Eskişehir, Anadolu Üniversitesi Publications, 2014)

16. E.H. Kilicbeyli, E. Emrahov, From the 'Great Game' to 'New Great Game'( 1920-2002 years), Central Asian Reality In Light Of Recent Power Struggles (Gündoğan Publications, Istanbul, 2004)

17. D.C. King, Azerbaijan (Marshall Cavendish, UK, 2006)

18. R. Karimov, Evaluation of demographic sustainability in Azerbaijan, GISAP:Sociol., Polit. and Military Sci. 6 (2015) https://doi.org/10.18007/gisap:spms.v0i6.973

19. S.G. Luzyanin, Eastern Politics of Vladimir Putin (M., Vostok-Zapad Izdatelstva, 2007)

20. E.H. Mikail, H. Çora, A.N. Çora, Azerbaijan's energy resources and BTC (Bakü Tbilisi Ceyhan is the name given to the pipeline project being built for crude oil transfer) project, Open Journal of Political Science 10, 02, 163-184 (2020) https://doi.org/10.4236/ojps.2020.102012

21. M.A. Mammadali, K.B. Gabil, Transport infrastructure as a factor of economic growth in Azerbaijan, Journal of Social and Development Sciences 8, 3, 35-39 (2017) https://doi.org/10.22610/jsds.v8i3.1973

22. S. Mukhtarov, J. Mammadov, F. Ahmadov, The impact of oil prices on inflation: The case of Azerbaijan, International Journal of Energy Economics and Policy 9(4), 97-102 (2019) https://doi.org/10.32479/ijeep.7712

23. H. Onder, Azerbaijan (2012) https://doi.org/10.1596/978-0-8213-9759-6 